\title{
Formation of bone-like apatite layer on chitosan fiber mesh scaffolds by a biomimetic spraying process
}

\author{
K. Tuzlakoglu $\cdot$ R. L. Reis
}

Received: 1 January 2006/ Accepted: 1 May 2006/Published online: 13 March 2007

(C) Springer Science+Business Media, LLC 2007

\begin{abstract}
Bone-like apatite coating of polymeric substrates by means of biomimetic process is a possible way to enhance the bone bonding ability of the materials. The created apatite layer is believed to have an ability to provide a favorable environment for osteoblasts or osteoprogenitor cells. The purpose of this study is to obtain bone-like apatite layer onto chitosan fiber mesh tissue engineering scaffolds, by means of using a simple biomimetic coating process and to determine the influence of this coating on osteoblastic cell responses. Chitosan fiber mesh scaffolds produced by a previously described wet spinning methodology were initially wet with a Bioglass ${ }^{\circledR}$-water suspension by means of a spraying methodology and then immersed in a simulated body fluid (SBF) mimicking physiological conditions for one week. The formation of apatite layer was observed morphologically by scanning electron microscopy (SEM). As a result of the use of the novel spraying methodology, a fine coating could also be observed penetrating into the pores, that is clearly within the bulk of the scaffolds. Fourier Transform Infrared spectroscopy (FTIRATR), Electron Dispersive Spectroscopy (EDS) and $\mathrm{X}$-ray diffraction (XRD) analysis also confirmed the presence of apatite-like layer. A human osteoblast-like cell line (SaOs-2) was used for the direct cell contact
\end{abstract}

K. Tuzlakoglu $(\bowtie) \cdot$ R. L. Reis

3B's Research Group - Biomaterials, Biodegradables

and Biomimetics, Univ. Minho, Campus de Gualtar,

4710-057 Braga, Portugal

e-mail: kadriye@dep.uminho.pt

K. Tuzlakoglu $\cdot$ R. L. Reis

Department of Polymer Engineering, University of Minho,

Campus de Azurém, 4800-058 Guimarães, Portugal assays. After 2 weeks of culture, samples were observed under the SEM. When compared to the control samples (unmodified chitosan fiber mesh scaffolds) the cell population was found to be higher in the $\mathrm{Ca}-\mathrm{P}$ biomimetic coated scaffolds, which indicates that the levels of cell proliferation on this kind of scaffolds could be enhanced. Furthermore, it was also observed that the cells seeded in the Ca-P coated scaffolds have a more spread and flat morphology, which reveals an improvement on the cell adhesion patterns, phenomena that are always important in processes such as osteoconduction.

\section{Introduction}

Bone is a complex, dynamic and highly vascular tissue with a large amount of extracellular matrix. In nanoscale, bone matrix consists of highly organized collagen fibers surrounded by apatite crystals [1]. Due to this very specialized structure, repair or replacement of damaged or traumatized bone still remains as a serious problem in surgery. For many years, autografts and allografts have been used for bone repair. However, there are many limitations and complications in the use of autogratfs and allografts, including limited supply, donor site morbidity and transfer of diseases.

Engineering of bone tissue is a new approach to recreate complexity, stability and biologic function of bone tissue. The most common strategy for the tissue engineering of bone is to use a scaffold combined with osteoblast or the cells that can mature/differentiate into osteoblasts and regulating factors that promote 
cell attachment, differentiation and mineralized bone formation [2]. To serve as a scaffold for bone tissue engineering, the material should be biocompatible, biodegradable and porous with an interconnective pore structure in order to allow nutrients and metabolites to permeate. Furthermore, it must also be osteoconductive, so that osteoblasts and osteoprogenitor cells can attach and migrate in the scaffold.

Calcium phosphate ceramics and bioactive glasses have been proposed to be used as a scaffold for bone tissue engineering due to their excellent osteoconductivity $[3,4]$. It has been shown that they can bind to bone trough an apatite layer at the interface or bind directly to bone [5]. However, they cannot serve alone as a scaffold because of their brittleness and low resistance against impact loading.

Biodegradable polymers have been proposed as possible alternatives and received much attention as bone replacement materials [6-8]. They can be easily processed into 3-D porous structures with a proper degradation rate and mechanical strength. However, most of them are not show bioactivity without any surface modification. To overcome this problem, the surface of the material can be coated with HA or apatite. A number of methods, such as plasma spraying [9], ion sputtering [10], laser deposition [11], sol-gel deposition [12], dip coating sintering [13], have been used for apatite coating of the material surfaces. However, these processes need very high temperatures or very high/low $\mathrm{pH}$ that cannot be applied to the polymeric materials. In addition, the apatite formed by these processes is usually highly crystalline and has different crystal structure than that in natural bone apatite. Another drawback in these processes is the difficulties in obtaining a homogenous and a thin layer of coating on the surface of the material.

Biomimetic coating using simulated body fluid (SBF) has been developed by Kokubo and coworkers as an alternative to the methods discussed above [14]. They have reported that the formed apatite, so-called bone-like apatite, is more similar to natural bone with a low crystallinity and nano-cyrstal size, which is also an important issue in its degradation. Moreover, the conditions that are used in this process are very mild and allow applying a variety of polymeric and non-polymeric surfaces [15, 16]. For instance, Reis et al. [17-19] adapted and used this methodology for starch-based biodegradable polymers. Regarding the mechanism, it has been shown that the functional groups on the polymer surface, such as $\mathrm{Si}-\mathrm{OH}, \mathrm{Ti}-\mathrm{OH}$ and carboxyl or carboxylate, are the responsible for the apatite nucleation in SBF. Once the material with a functional surface im- mersed in SBF, which is already supersaturated with ions that constitute apatite, apatite nuclei starts to form and grow into a dense and uniform bone-like apatite layer [15]. One way to introduce functional $\mathrm{Si}-\mathrm{OH}$ group on the polymeric surfaces is to face the polymer with Bioglass ${ }^{\circledR}$ particles before immersion in SBF [20].

The objective of the present study is to obtain bonelike apatite layer on chitosan fiber mesh scaffolds by using the biomimetic approach. We developed a new methodology based on a simple spraying process in order to have a homogeneous coating on these complex structures. Moreover, we also tested the scaffolds with human osteoblast-like cell line (SaOs-2) to determine the influence of bone-like apatite coating on cell adhesion and viability.

\section{Materials and methods}

Chitosan (deacetylation degree $87 \%$ ), was obtained from Aldrich Chemical Co. Bioglass ${ }^{\circledR}$ with particle size of $5 \mu \mathrm{m}$ was kindly supplied by US Biomaterials Corp. (Florida, USA). All the other chemicals used were of analytical grade.

\section{Production of chitosan fiber mesh scaffolds}

Chitosan fibers were produced as previously reported [21]. In brief, chitosan was dissolved in aq. $2 \%(\mathrm{v} / \mathrm{v})$ acetic acid solution in $5 \%(\mathrm{w} / \mathrm{v})$ concentration at room temperature overnight. Methanol was added to dilute the viscous solution for easy injection until reaching $3 \%(\mathrm{w} / \mathrm{v})$ final concentration. Glycerol was used as a plasticizer $(2.5 \%(\mathrm{w} / \mathrm{w}))$. After filtration with a cloth filter, the solution was placed in an ultrasonic bath to remove the air bubbles. The clear solution was injected into a coagulation bath $(30 \%$ $1 \mathrm{~N} \mathrm{Na}_{2} \mathrm{SO}_{4}, 10 \% 1 \mathrm{~N} \mathrm{NaOH}$ and distilled water). The formed fibers were kept in this coagulation medium for one day and then washed several times with distilled water. They were then suspended in an aqueous $50 \%$ methanol solution for $1 \mathrm{~h}$ and subsequently in $100 \%$ methanol for $3 \mathrm{~h}$. The fibers were then put in a plastic cylindrical mould and dried at $60^{\circ} \mathrm{C}$ overnight.

\section{Biomimetic coating}

A simple methodology was developed for the biomimetic coating experiments. The method is basically based on spraying a Bioglass ${ }^{\circledR} /$ water suspension on the 
surface of the scaffolds. This spraying methodology allows for the coating of the bulk of the scaffold. Briefly, a certain amount of Bioglass ${ }^{\circledR}$ was suspended in ultra-pure water. Produced scaffolds could then be wet with this Bioglass ${ }^{\circledR}$-water suspension by using this simple methodology. After drying for a certain time under air flow, each sample was immersed in $40 \mathrm{~mL}$ of simulated body fluid (SBF) $(\times 1)$ (see Fig. 1$)$. The ion concentrations of SBF were approximately equal to those of human blood plasma. The tubes were put in an incubator at 37(C for 7 days. The solution and the tubes were renewed next day. After the first day of immersion, renewal was every 2 days for the solution. In the end of the immersion period, samples were washed with distilled water and dried at room temperature.

\section{Characterization of $\mathrm{Ca}-\mathrm{P}$ coated scaffolds}

In order to analyze the morphology of the $\mathrm{Ca}-\mathrm{P}$ layer formed on the scaffolds, the samples were mounted onto brass stubs, sputter coated with gold and analyzed under a Scanning Electron Microscope (SEM) at an accelerating voltage $15 \mathrm{kV}$. Electron Dispersive Spectroscopy (EDS) was also used to determine the presence of $\mathrm{Ca}$ and $\mathrm{P}$ in bioactive layers. To evaluate the changes on the chemical structure of sample surface, Fourier Transform Infrared Spectroscopy (FTIR-ATR) was used. Thin Film X-ray diffraction (TF-XRD) was used for identifying the crystalline phases present, and characterizing the crystalline/ amorphous nature of the formed $\mathrm{Ca}-\mathrm{P}$ bioactive layers.

\section{Cell culture studies with osteoblasts}

A human osteoblasts SaOs-2 cell line was selected to study cell morphology, attachment and proliferation onto Ca-P coated chitosan fiber meshes scaffolds. Cells cultured in DME Media (Sigma), enriched with 10\% FBS (Biochrome) and 1\% antibiotic/antimicotic solution (Sigma) were seeded directly over samples in a concentration of $2 \times 10^{6}$ cells/scaffold. Incubation was performed at $37^{\circ} \mathrm{C}\left(5 \% \mathrm{CO}_{2}, 100 \%\right.$ humidity $)$ for 3 weeks. Uncoated samples were used as a control.
After each incubation period, samples were washed with Phosphate Buffer Saline (PBS, Sigma) solution and fixed in gluteraldehyde $2.5 \%(\mathrm{v} / \mathrm{v})$. For Scanning Electronic Microscopy (SEM) observation, samples were previously dehydrated in increasing alcohol concentrations $(50 \%, 70 \%, 90 \%$ and $100 \%)$, air-dried and sputter coated with gold.

\section{Cell viability}

A MTS assay was carried out to determine the cell viability after 3 weeks of culture by using Cell Titer $96^{\circledR}$ Aqueous One Solution Cell proliferation Assay kit (Promega, USA). This test is based on the bioreduction of the substrate, (3-(4,5-dimethylthiazol2-yl)-5-(3-carboxymethoxyphenyl)-2(4-sulfophenyl)-2H tetrazolium) (MTS), into a brown formazan product by NADPH or NADP produced by dehydrogenase enzymes in metabolically active cells. According to the standard procedure, the triplicates of samples were placed in a new plate and fresh medium was added to each well. MTS reagent in 5/1 ratio was added to each well and then incubated for $3 \mathrm{~h}$ at $37^{\circ} \mathrm{C}$ in a humidified atmosphere containing $5 \%$ of $\mathrm{CO}_{2}$. A $100 \mu \mathrm{l}$ of incubated medium was transferred to 96-well plate culture plate and the optical density was read at $490 \mathrm{~nm}$ in a micro-plate reader (Synergy HT, Bio-tek).

\section{Alkaline phosphatase (ALP) activity}

In order to determine the amount of alkaline phosphatase (ALP) produced by the cells seeded on the scaffolds, scaffolds/cells constructs were washed, freeze-thawed and sonicated after 3 weeks of culture. $p$-Nitrophenyl phosphate ( $\mathrm{pNPP}$ ) was added to the supernatant in the ratio of $1 / 3$ and incubated at $37^{\circ} \mathrm{C}$ for $1 \mathrm{~h}$. The enzyme reaction was then stopped by a solution containing $2 \mathrm{M} \mathrm{NaOH}$ and $0.2 \mathrm{mM}$ EDTA in distilled water. The absorbance of $p$-nitrophenol (pNP) formed was determined at $405 \mathrm{~nm}$ with a reference filter at $620 \mathrm{~nm}$. A standard curve was made using $\mathrm{pNP}$ values ranging from $0 \mu \mathrm{mol} / \mathrm{mL}$ to $600 \mu \mathrm{mol} / \mathrm{mL}$. The results were expressed as $\mu \mathrm{mol}$ of $\mathrm{pNP}$ produced/ $\mathrm{mL} / \mathrm{h}$.
Fig. 1 Shematic

representation of a novel biomimetic $\mathrm{Ca}-\mathrm{P}$ coating process using a simple spray

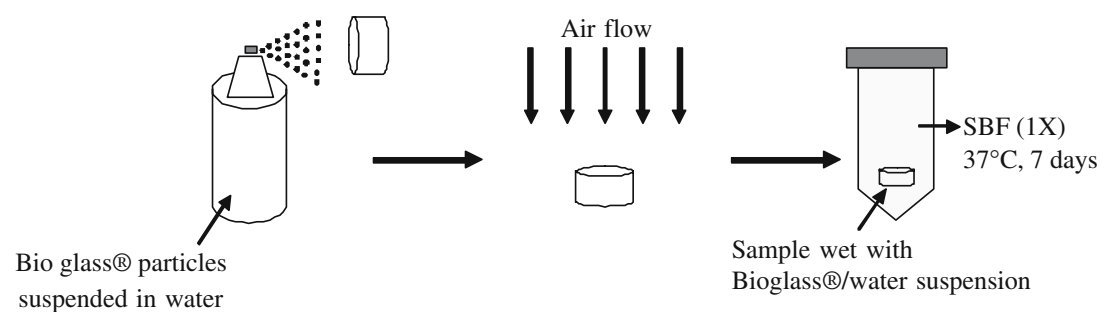




\section{Results and discussion}

Biomimetic coating

The scaffolds used in this study were porous chitosan fiber meshes of a cylindrical shape with a diameter of $1 \mathrm{~cm}$ (Fig. 2). The structure is made of randomly oriented fibers with an average diameter of $100 \mu \mathrm{m}$ and these fibers form a highly interconnected nest-like structure as it can be seen from SEM micrographs (see Fig. 3a, b). As we have reported before [21], these scaffolds have a very high water uptake ability, which can of course provide better adhesion of Bioglass ${ }^{\circledR}$ particles on the surface of the fiber during the biomimetic coating process. However, the coating of biodegradable scaffolds with biomimetic $\mathrm{Ca}-\mathrm{P}$ layers is rather difficult and not many examples of this can be found on the literature $[22,23]$.

SEM micrographs of $\mathrm{Ca}-\mathrm{P}$ coated chitosan fiber mesh scaffolds were given in Fig. 4. After Bioglass ${ }^{\circledR}$ spraying to the samples, a fine and homogenous $\mathrm{Ca}-\mathrm{P}$ layer was observed on their surface after 7 days soaking in SBF solution. Kokubo et al. [24, 25] proposed the mechanism of bone-like apatite formation on polymeric surfaces when $\mathrm{CaO}-\mathrm{SiO}_{2}$ glass particles are used as a nucleation-inducing agent. According to this mechanism, silicate ions released from the glass particles are attached on the polymer surface and $\mathrm{Si}-\mathrm{OH}$ groups in the silicate ions induce the apatite nucleation on the surface. At the same time, the release of calcium ions from glass particles increases the ionic activity product of SBF with respect to apatite and accelerates the apatite nucleation. Finally, the apatite nuclei formed on the surface grow spontaneously by consuming $\mathrm{Ca}$ and $\mathrm{P}$ ions from the fluid. Using this approach, many flat polymeric surfaces have been coated with bone-like apatite by rolling the

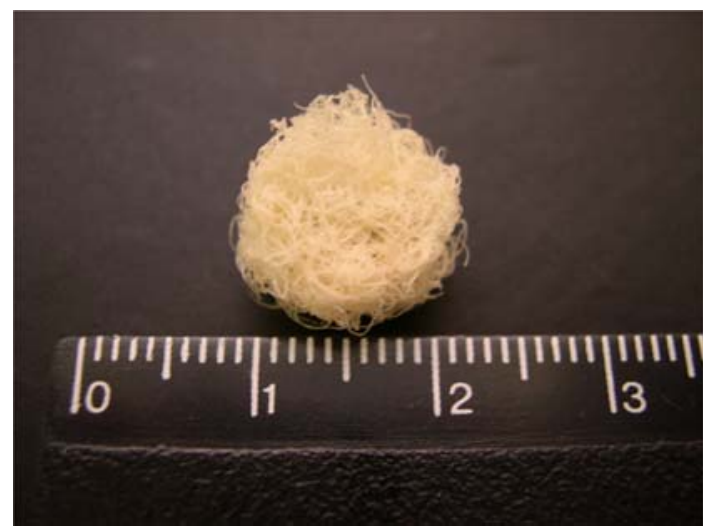

Fig. 2 Chitosan fiber mesh scaffolds produced by wet spining

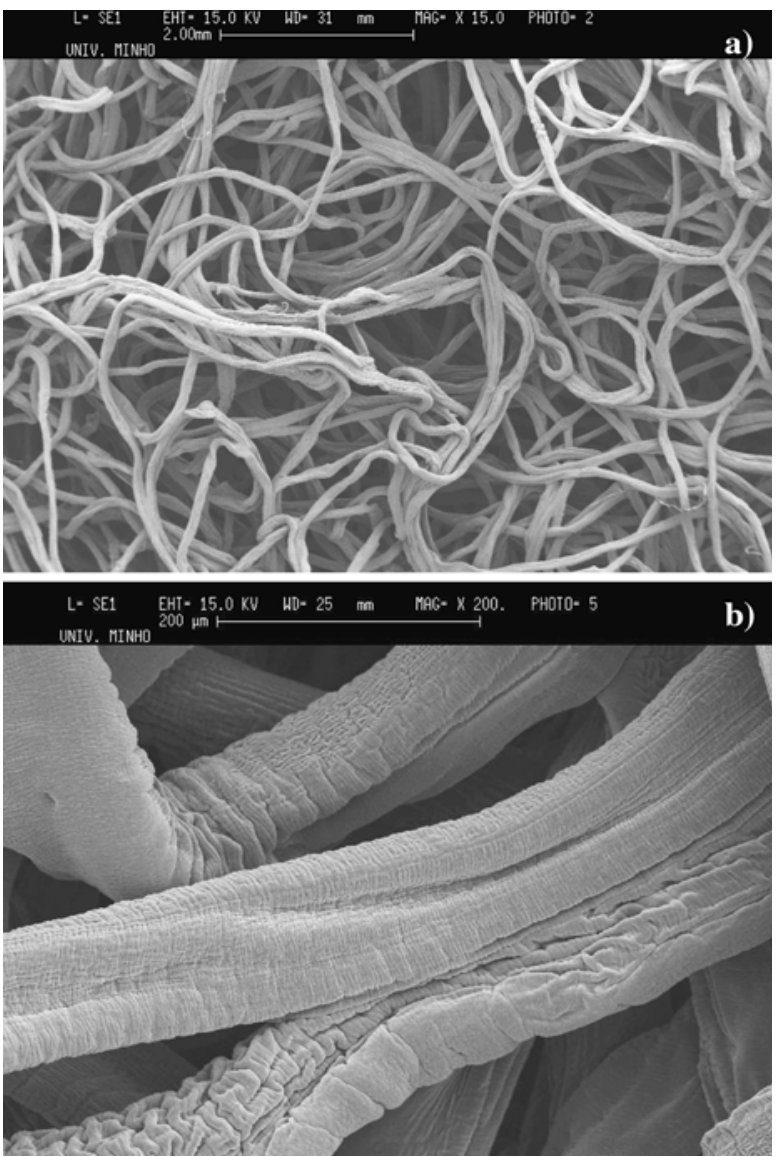

Fig. 3 SEM micrographs of chitosan fiber mesh scaffolds; (a) $\times 15$, (b) $\times 200$

samples in Bioglass ${ }^{\circledR} /$ water suspension [26]. However, the rolling process is not suitable for more complex surfaces due to the non-homogenous distribution of Bioglass ${ }^{\circledR}$ particles. Therefore, we developed a simple spraying method, which allowed a homogenous distribution of glass particles on the scaffold surface as well as inside the structure. As a result of this method, a homogenous bone-like apatite layer was observed on the individual fibers. Moreover, it was also possible to see the typical cauliflower morphology of bone-like apatite layer in SEM micrographs with a higher magnification (Fig. 4d). The EDS spectra of the coated samples confirmed the formation of apatite layer by showing the $\mathrm{Ca}$ and $\mathrm{P}$ elements (Fig. 5). The typical $\mathrm{Ca}-\mathrm{P}$ ratio was around $1.6 \pm 0.10$ which is similar to natural bone apatite.

Figure 6 shows FTIR spectra of control (uncoated chitosan fiber meshes) and biomimetic $\mathrm{Ca}-\mathrm{P}$ coated chitosan fiber meshes. Uncoated samples presented the characteristic absorption bands of chitosan, which are a wide band associated with $-\mathrm{OH}$ group at around $3,400 \mathrm{~cm}^{-1}$ and a band associated with glycosidic 
Fig. 4 SEM micrographs of the developed coated scaffolds, exhibiting a fine and homogenous $\mathrm{Ca}-\mathrm{P}$ layer onto chitosan fiber meshes surfaces; (a) $\times 100,(\mathbf{b}) \times 300$, (c) 500, (d) $\times 5,000$
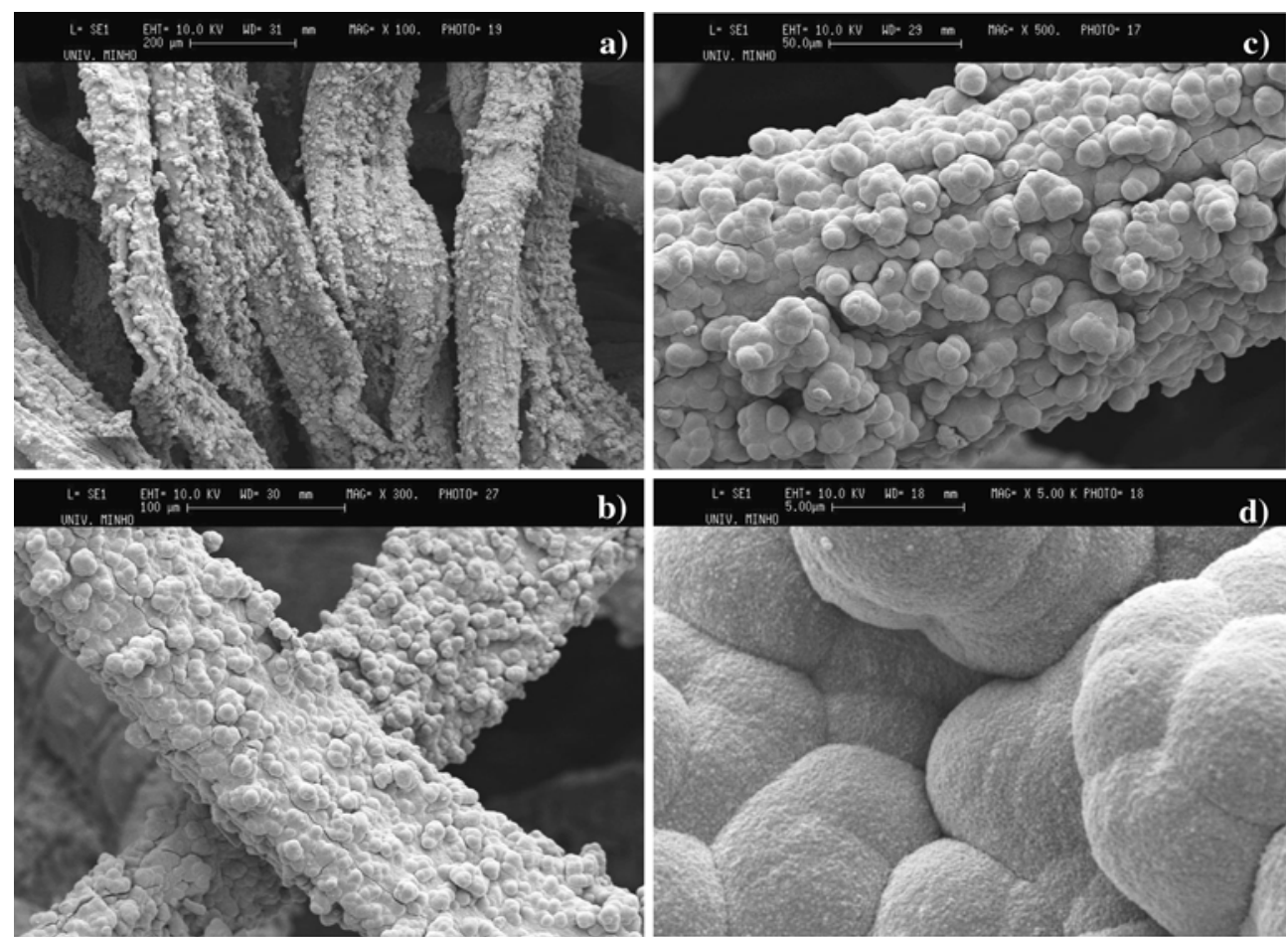

linkage at around $1,050 \mathrm{~cm}^{-1}$. After $\mathrm{Ca}-\mathrm{P}$ coating of the surface, the characteristic band attributed to $-\mathrm{OH}$ tend to disappear while a sharp band appeared at $1,030 \mathrm{~cm}^{-1}$, which is a characteristic $\mathrm{P}-\mathrm{O}$ stretching band. The decrease in the intensity of $-\mathrm{OH}$ stretching group might be due to the increase in the carbonate substitution as has been reported by the others [27, 28]. It has been suggested that when the carbonate substitution increase, carbonate ions replace with hydroxyl ions [28]. These results demonstrated that the surfaces of the chitosan fibers were completely coated by a carbonated apatite layer.

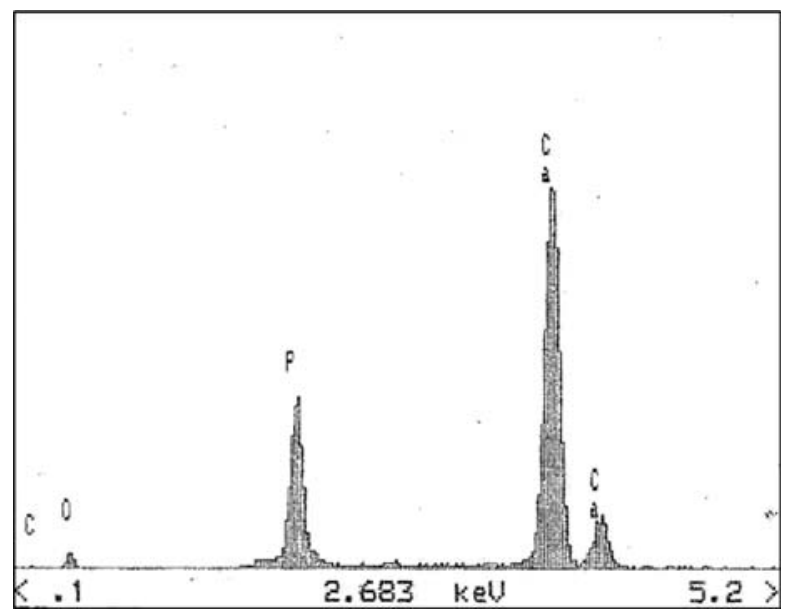

Fig. 5 EDS spectra of Ca-P coated chitosan fiber mesh scaffolds

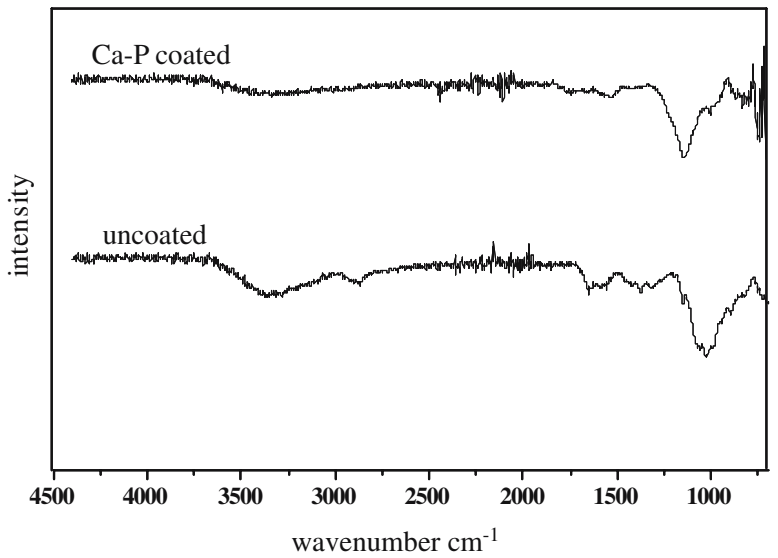

Fig. 6 FTIR spectra of $\mathrm{Ca}-\mathrm{P}$ coated sample and uncoated sample

Thin-film XRD of the samples immersed in SBF for 7 days is presented in Fig. 7. The main diffraction peak at $2 \theta=32^{\circ}$ is a contribution of (211), (300) and (202) planes of apatite. Another main diffraction peak at $2 \theta=26^{\circ}$ indicated the (002) lattice plane of apatite crystals. Other diffraction peak of apatite appeared around at $2 \theta=40^{\circ}$ as it was marked in Fig. 7. The broad peak at around $2 \theta=20^{\circ}$ was due to the chitosan. The intensity of this peak decreased after coating which confirms once again the apatite layer on the surface of fibers. 


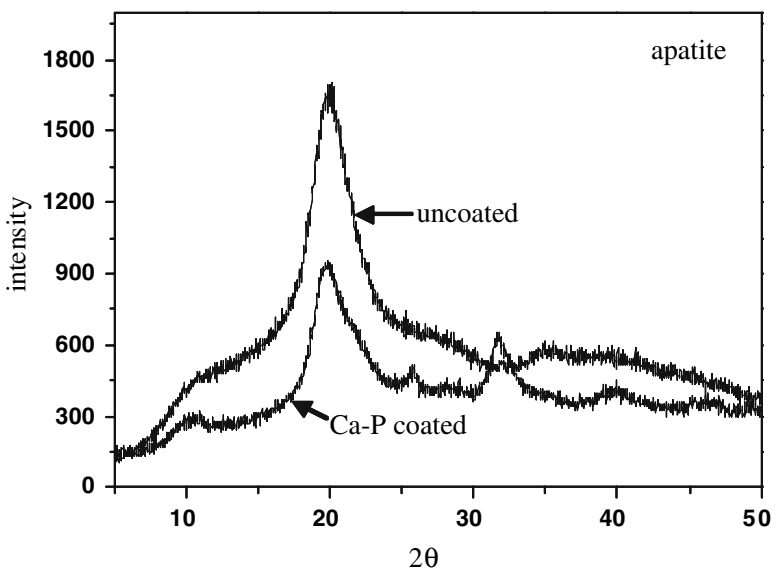

Fig. 7 Thin-film XRD patterns of the chitosan fiber meshes immersed in SBF for 7 days

Cell culture studies with osteoblasts

Figures 8 and 9 exhibit the SEM micrographs of osteoblasts seeded on the surface of $\mathrm{Ca}-\mathrm{P}$ coated and uncoated samples after 2 and 3 weeks of culture, respectively. The cells were observed to be able to attach and to proliferate in both surfaces. However, they seemed to be more spread and presented a different morphology when the surface was pre-coated with a $\mathrm{Ca}-\mathrm{P}$ layer. This is a result of the changes in the surface chemistry of the scaffolds. Several investigators have reported that the surface chemistry and the topography can directly affect the osteoblast response and determine cell attachment and alignment [29-31]. Depending on the surface composition and the topography, protein, ligands and integrins can adsorb to the surface in different structures and adhesion kinetics [32]. Due to the different interaction between the adhesion ligands adsorbed to different surfaces and the adhesion receptors of the cells, cells can generate different adhesion signals. These adhesion signals influence further cell attachment and morphology. In the present study, it was not possible to evaluate the effect of surface topography because of the irregular surface structure of the chitosan fibers. However, we can say that the surface chemistry has a clear influence on cell attachment and morphology. The difference on the cell spreading behavior could also be observed clearly with a longer culturing time. The osteoblasts started to form a complete layer on the surface of fibers after 3 weeks of culture (Fig. 9b).

The Ca-P coating also influenced the long-term cell viability on the scaffolds. Figure 10 shows the MTS results after 3 weeks of culture. MTS is an indirect assay to determine the metabolic activity and number
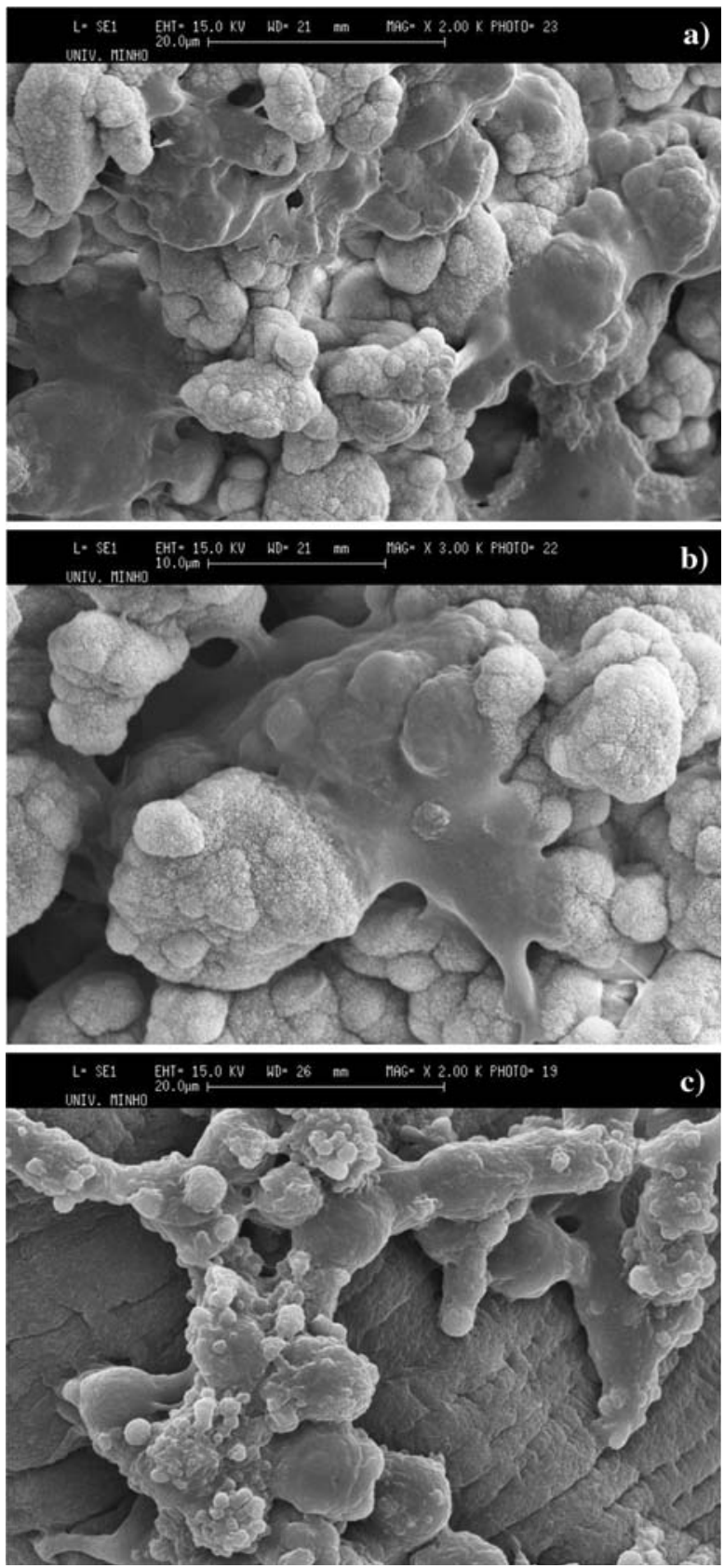

Fig. 8 Human osteoblast like cells seeded on (a) Ca-P coated $(\times 2,000),(\mathbf{b}) \mathrm{Ca}-\mathrm{P}$ coated $(\times 3,000)$ and $(\mathbf{c})$ uncoated $(\times 2,000)$ chitosan fiber mesh scaffolds after 2 weeks of culture

of the cells. As it can be seen, osteoblasts seeded on the $\mathrm{Ca}-\mathrm{P}$ coated scaffolds showed higher O.D. value than control samples which means metabolic activity and number of cells were higher in the $\mathrm{Ca}-\mathrm{P}$ coated samples. This can be related to the enhanced cell attachment on the Ca-P coated samples. In fact, it has been reported that initial cell attachment affects further proliferation of the cells [33].

ALP is a well-known enzyme used as a marker of the osteogenic phenotype, which catalyzes the hydro- 

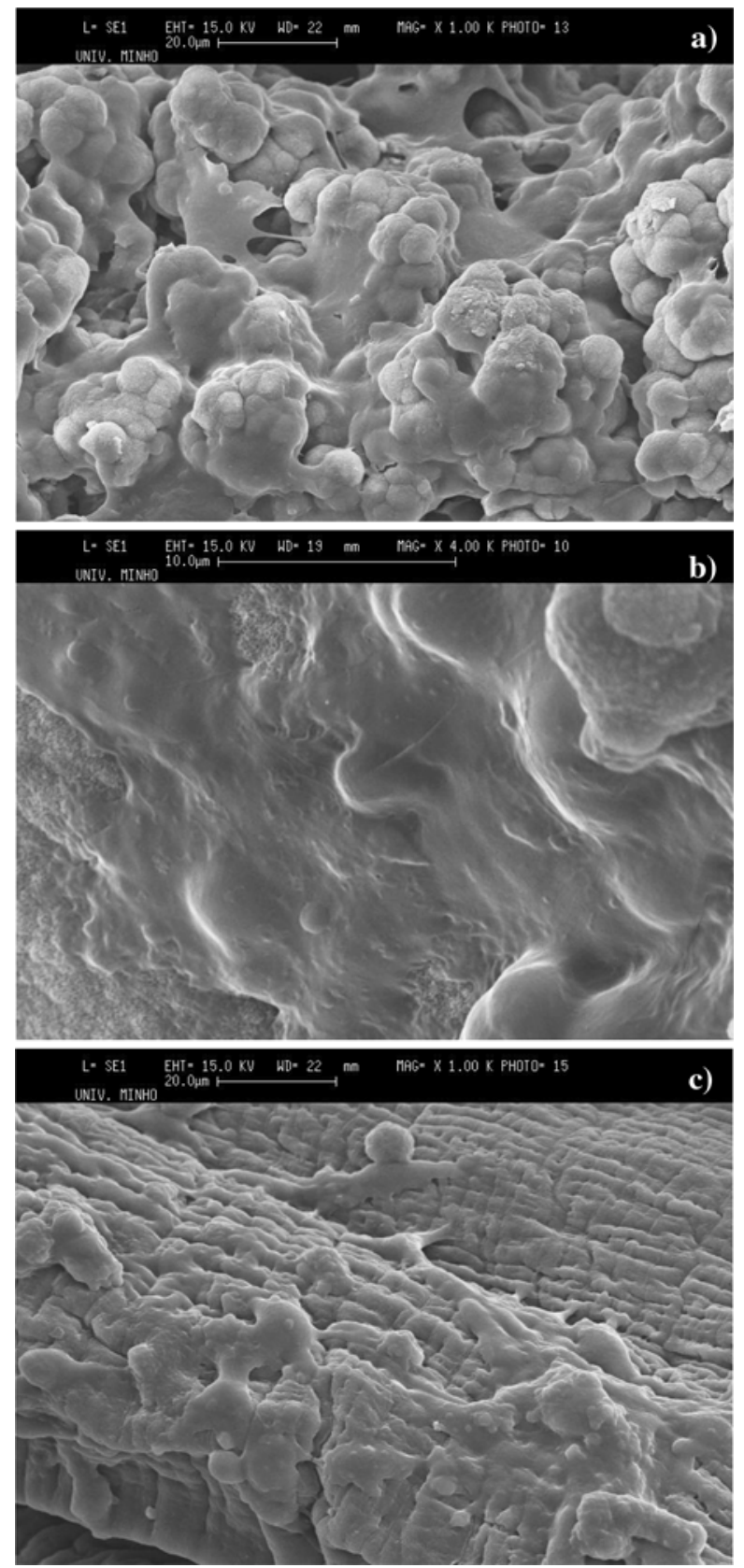

Fig. 9 Human osteoblast like cells (SaOs-2) seeded on (a) $\mathrm{Ca}-\mathrm{P}$ coated $(\times 1,000),(\mathbf{b}) \mathrm{Ca}-\mathrm{P}$ coated $(\times 4,000)$ and $(\mathbf{c})$ uncoated $(\times 1,000)$ chitosan fiber mesh scaffolds after 3 weeks of culture

lysis of phosphate esters at an alkaline $\mathrm{pH}$ [34]. It has been also demonstrated that it plays an important role in bone matrix mineralization process. Figure 11 presents the ALP activity of the cells cultured on the coated and control scaffolds. ALP activity of the cells seeded on the $\mathrm{Ca}-\mathrm{P}$ scaffolds were found significantly higher than that on control. One possible reason for that can be the release of the $\mathrm{Ca}^{2+}$ ions from the coating to the culture medium. Matsuoka et al. [35]

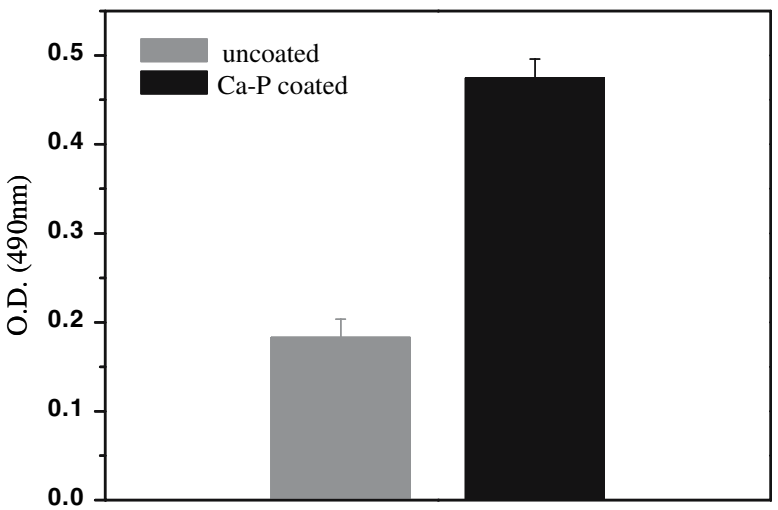

Fig. 10 Cell viability and proliferation of human osteoblast like cells determined by MTS after 3 weeks of culture. Error bars represent means $\pm \mathrm{SD}$ for $n=3$

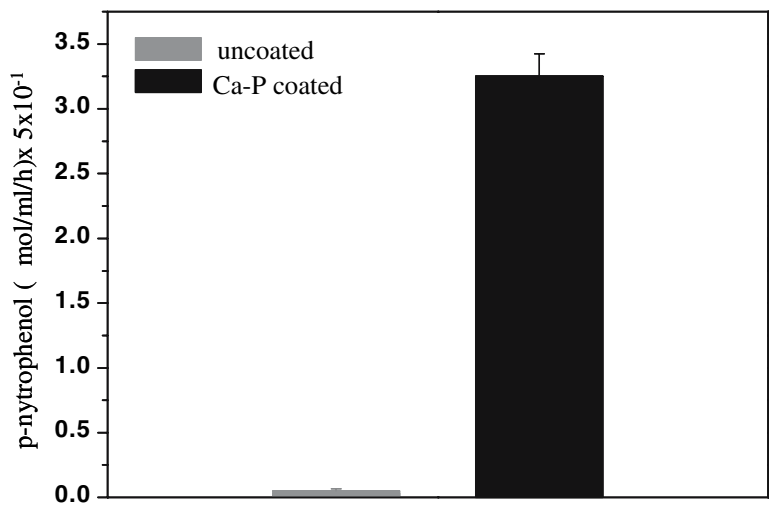

Fig. 11 The ALP activity of human osteoblast like cells seeded on $\mathrm{Ca}-\mathrm{P}$ coated scaffolds and control (uncoated scaffolds). Error bars represent means \pm SD for $n=3$

showed that ALP activity and osteogenic differentiation of osteoblastic cells increased if there is an increase of $\mathrm{Ca}$ concentration in culture medium by release from the apatite. However, further studies are still needed to understand the details of mechanism of the cellular response to $\mathrm{Ca}-\mathrm{P}$ coating that is described herein.

\section{Conclusions}

A novel and simple biomimetic approach was described for the preparation of bone-like apatite coated chitosan scaffolds. Fiber mesh type scaffolds could be prepared from chitosan by a wet spinning method. A homogenous $\mathrm{Ca}-\mathrm{P}$ coating was produced on the surface and the bulk of chitosan scaffolds by means of using the proposed methodology. After 7 days of immersion in the SBF solution, a fine and homogenous 
bone-like apatite layer was observed on the surface of chitosan fibers. Furthermore, osteoblasts adhered on $\mathrm{Ca}-\mathrm{P}$ coated samples showed a more spread and distinct morphology. Higher cell numbers were observed on the caoted scaffolds as compared to the uncoated samples. On the basis of these results, $\mathrm{Ca}-\mathrm{P}$ coated scaffolds obtained by the proposed biomimetic process can be useful to be used as a bone tissue engineering scaffolds.

Acknowledgements K. Tuzlakoglu thanks the Portuguese Foundation for Science and Technology for providing her a PhD scholarship (SFRH/BD/8502/2002). This work was partially supported by FCT Foundation for Science and Technology, through funds from the POCTI and/or FEDER programmes and by the European Union funded STREP Project HIPPOCRATES (NMP3-CT-2003-505758). This work was carried out under the scope of the European NoE EXPERTISSUES (NMP3-CT-2004-500283).

\section{References}

1. S. WEINER and H. D. WAGNER, Ann. Rev. Mater. Sci. 28 (1998) 271

2. A. G. MIKOS and J. S. TEMENOFF, J. Biotech. 3 (2000) 114

3. T. L. ARINZEH, T. TRAN, J. MCALARY and G. DACULSI, Biomaterials 26 (2005) 3631

4. M. C. KRUYT, W. J. A. DHERT, H. YUAN, C. E. WILSON, C. A. BLITTERSWIJK, A. J. VERBOUT and J. D. BRUJIN, J. Orthop. Res. 22 (2004) 544

5. P. A. RAMIRES, A. ROMITO, F. COSENTINO and E. MILELLA, Biomaterials 22 (2001) 1467

6. D. W. HUTMACHER, Biomaterials 21 (2000) 2529

7. M. E. GOMES, J. S. GODINHO, D. TCHALAMOV, M. A. CUNHA and R. L. REIS, Mater. Sci. Eng. C 20 (2002) 19

8. A. J. SALGADO, O. P. COUTINHO and R. L. REIS, Tissue Eng. 10 (2004) 465

9. L. SUN, C. C. BERNDT, K. A. GROSS and A. KUCUK, J. Biomed. Mater. Res.: Appl. Biomat. 58 (2001) 570

10. F. Z. CUI, Z. S. LUO and Q. L. FENG, J. Mater. Sci.: Mater. Med. 8 (1997) 403

11. A. BIGI, B. BRACCI, F. CUISINIER, R. ELKAIM, M. FINI, I. MAYER, I. N. MIHAILESCU, G. SOCOL, L. STURBA and P. TORRICELLI, Biomaterials 26 (2005) 2381
12. M. SATO, E. B. SLAMOVICH and T. J. WEBSTER, Biomaterials 26 (2005) 1349

13. C. S. KIM and P. DUCHEYNE, Biomaterials 12 (1991) 461

14. Y. ABE, T. KOKUBO and T. YAMAMURO, J. Mater. Sci.: Mater. Med. 1 (1990) 233

15. H. M. KIM, K. KISHIMOTO, F. MIYAJI, T. KOKUBO, T. YAO, Y. SUETSUGU, J. TANAKA and T. NAKAMURA, J. Biomed. Mater. Res. 46 (1999) 228

16. M. TANAHASHI, T. YAO, T. KOKUBO, M. MINODA, T. MIYAMOTO, T. NAKAMURA and T. YAMAMURO, J. Appl. Biomater. 5 (1994) 339

17. A. L. OLIVEIRA, C. M. ALVES and R. L. REIS, J. Mater. Sci.: Mater. Med. 13 (2002) 1181

18. A. L. OLIVEIRA, P. B. MALAFAYA and R. L. REIS, Biomaterials 24 (2003) 2575

19. H. S. AZEVEDO, I. B. LEONOR, C. M. ALVES and R. L. REIS, Mater. Sci. Eng. C 25 (2005) 169

20. M. Tanahashi, T. Yao, T. Kokubo, M. Minoda, T. Miyamoto, T. Nakamura and T. Yamamuro, J. Am. Ceram. Soc. 77 (1994) 2805

21. K. TUZLAKOGLU, C. M. ALVES, J. F. MANO and R. L. REIS, Macromol. Biosci. 4 (2004) 811

22. A. OYANE, M. UCHIDA, C. CHOONG, J. TRIFFITT, J. JONES and A. ITO, Biomaterials 26 (2005) 2407

23. R. ZHANG and P. X. MA, Macromol. Biosci. 4 (2004) 100

24. C. OTHSUKI, T. KOKUBO and T. YAMAMURO, J. NonCryst. Solids 143 (1992) 84

25. P. LI, C. OHTSUKİ, T. KOKUBO, K. NAKANISHI, N. SOGA, T. NAKAMURA and T. YAMAMURO, J. Am. Ceram. Soc. 75 (1992) 2094

26. R. L. REIS, A. M. CUNHA, M. H. FERNANDES and R. N. CORREIA, J. Mater. Sci.: Mater. Med. 8 (1997) 897

27. I. REHMAN and W. BONFIELD, J. Mater. Sci.: Mater. Med. 8 (1997) 1

28. J. C. ElliotT, D. W. HOLCOM and R. A. YOUNG, Calcif. Tissue Int. 37 (1985) 372

29. J. LINCKS, B. D. BOYAN, C. R. BLANCHARD, C. H. LOHMANN, Y. LUI, D. L. COCHRAN, D. D. DEAN and Z. SCHWARTZ, Biomaterials 19 (1998) 2219

30. T. J. WEBSTER, R. W. SIEGEL and R. BIZIOS, Biomaterials 20 (1999) 1221

31. J. L. ONG, D. R. VILLARREAL, R. CAVIN and K. MA, J. Mater. Sci.: Mater. Med. 12 (2001) 491

32. D. R. VILlaREAL, A. SOGAL and J. L. ONG, J. Oral. Implant. 22 (1998) 67

33. K. ANSELME, Biomaterials 21 (2000) 667

34. H. HARRIS, Clinica Chimica Acta 186 (1989) 133

35. H. MATSUOKA, H. AKIYAMA, Y. OKADA, H. ITO, C. SHIGENO, J. KONISHI, T. KOKUBO and T. NAKAMURA, J. Biomed. Mater. Res. 47 (1999) 176 